\title{
The Chemical Degradation of Leather
}

\author{
René Larsen*
}

\begin{abstract}
The chemical deterioration of vegetable tanned leather is caused by acid hydrolysis and oxidation due to environmental deteriorative factors like air pollutants, heat and light. In addition, the type of tannin material influences the rate of deterioration. The degree of deterioration can be measured by the fall in the shrinkage temperature (Ts) of the leather. New analysis of data shows that, although environmental factors have a generally larger influence on the deterioration, the average degree of oxidation is greater in older leathers and it significantly influences the Ts in these materials. Moreover, it is also shown that acid pollution is indicated in the relation between $\mathrm{pH}$ and the sulphate content measured in the leathers although ammonia is released by oxidation of amino acids and may influence the $\mathrm{pH}$ value in acid-damaged leathers.
\end{abstract}

Keywords: Acid hydrolysis · Deterioration · Oxidation $\cdot$ Shrinkage temperature $\cdot$ Vegetable tanned leather

\section{Introduction}

Leather degradation is a major topic in conservation studies. There seems to be no or very few possibilities of active conservation or restoration of ancient leathers. For this reason, a detailed understanding of the causes and mechanisms of deterioration is of great importance for the preventive conservation of leather artefacts.

All types of leathers are produced from the dermis of mammalian hide and skin, the main constituent of which is the fibrous protein collagen type I. Tannage of hide is achieved by incorporation of water-soluble tannin compounds like plant poly phenols, aluminium (e.g. $\left.\mathrm{KAl}\left(\mathrm{SO}_{4}\right)_{2} \cdot 12 \mathrm{H}_{2} \mathrm{O}\right)$ and chrome compounds ( $\mathrm{Cr}$ (III) salts) into the collagen fibre matrix. Other tannin materi- als are, for example, fish oils and reactive volatile compounds from smoke. In the following, the description of deterioration will focus on vegetable tanned leathers as this leather type is the most common in archives, libraries and museums and the most studied. However, details on the deterioration of other leather types can be found in the literature. ${ }^{[1-8]}$ Heavily deteriorated vegetable tanned leathers are characterised by severe disintegration of the fibre structure, which in the worst cases is turned into a powder. Although brittle in some cases, the pronounced powdering which characterises the vegetable tanned leather is not observed by other leather types or parchment. This indicates that the powdering phenomena may be linked to the relative large vegetable tannin molecules which fill the fibre network and, by condensation and establishing of strong tannin-collagen bonds, may stiffen and make the fibres brittle and easy breakable.

\section{Experimental}

\subsection{Determination of Shrinkage Temperature (Ts)}

The measurement of the shrinkage temperature (Ts) is based on the visual microscopic observation of a characteristic shrinkage activity of the leather fibres when heated in water. Observations were performed on samples of around $0.3 \mathrm{mg}$ fibres taken from the corium part (flesh side) of the parchment. On a microscope slide leather fibres were embedded in distilled water; the preparation being enclosed by a cover slip. The preparation was then heated at a rate of $2{ }^{\circ} \mathrm{C} / \mathrm{min}$ on a Mettler FP82 Hot
Stage controlled by a Mettler FP90 Central Processor. To observe the shrinkage movement the hot stage was placed under a stereomicroscope using a magnification of around 40 times. Ts observation is defined by the temperature at which at least two fibres shrink simultaneously. The accuracy of observation is $\pm 2{ }^{\circ} \mathrm{C}$.

\subsection{Determination of Basic (B) and Acidic (A) Amino Acid Ratios}

For the determination of $\mathrm{B} / \mathrm{A}$ ratios, i.e. the ratio of the sum in $\%$ mol of basic (B) and acidic (A) amino acids, samples of about $0.1 \mathrm{mg}$ of the parchment corium (flesh side) were taken. Only the corium part of the material should be used, as it consists mainly of collagen type I fibres. It is important to avoid the grain layer, which may also contain elastin as well as keratin from remains of hairs and hair follicles. The samples were hydrolyzed for $24 \mathrm{~h}$ in an evacuated and sealed glass ampoule at $110{ }^{\circ} \mathrm{C}$ in a solution consisting of $300 \mu \mathrm{l} 6$ $\mathrm{M}$ redistilled $\mathrm{HCl}, 15 \mu \mathrm{l}$ 2\% 3,3'-dithiodipropionic acid (DTDPA) in $0.2 \mathrm{M} \mathrm{NaOH}$ and $15 \mu \mathrm{l}$ of a $1 \%$ phenolic solution in water. After hydrolysis, the amino acids were separated by ion-exchange HPLC (Waters, USA). ${ }^{[9,10]}$ The amino acids were identified and quantified on the basis of an external standard mixture of amino acids (Beckman no. 33 1018, added Hyp and Hyl). The deviation of the total analysis is normally below $3 \%$. The parameter used as a measure of the average degree of oxidative modification of the leather collagen is the so-called B/A ratio, i.e. the ratio of the sum in $\%$ mol of basic (B) and acidic (A) amino acids, where $\mathrm{B} / \mathrm{A}=$ =Arg, Hyl, Lys/ AAsp, Glu. 


\subsection{Determination of Leather Acidity}

For measurement of their acidity, small leather samples were cut into around $1 \mathrm{~mm}^{2}$ fragments and extracted in deionised water at room temperature in a closed polyethylene vessel (50 $\mathrm{ml}$ water per $1 \mathrm{~g}$ of leather), for $24 h .{ }^{[1,12]} \mathrm{The} \mathrm{pH}$ of this aqueous extract was measured without removing the leather $(\mathrm{pH}(\mathrm{m})$ values). A small sample of this extract was used for ion analysis by high performance liquid chromatography. Results are expressed as concentrations (w/w) of sulphate, nitrate and chloride in the leather. Sulphate and nitrate were used to calculate what the $\mathrm{pH}$ of the extract would have been if they represented sulphuric and nitric acid, respectively (calculated $\mathrm{pH}$ or $\mathrm{pH}(\mathrm{c})$ values). From the difference between $\mathrm{pH}(\mathrm{m})$ and $\mathrm{pH}(\mathrm{c})$ the amount of ammonium sulphate present in the leather was calculated.

\section{The Chemical Breakdown Mechanisms}

The cause and mechanisms of the deterioration of vegetable tanned leather have been subject to studies for more than 150 years. ${ }^{[13]}$ More recent publications represent in a fine way the development in the study of deterioration of leather..$^{[2-8,13-19]}$ Moreover, reviews of the history of the study of leather and collagen deterioration can be found in the references [20] and [21].

The EC STEP leather project revealed the existence of both a hydrolytic acid and an oxidative breakdown mechanism. ${ }^{[20]}$ The acid hydrolysis leads to cleavage of the collagen peptide chains (Scheme 1).

The oxidative breakdown involves cleavage of the main chain of the collagen peptide chains as well as the modification of the side chains. Oxidation is most likely to take place at the carbon atoms adjacent to nitrogen as shown in Scheme 2 in the example of oxidative transformation of Arg into Glu.

The cause of the hydrolytic breakdown is mainly due to acidic pollution whereas the oxidative breakdown is mainly due to environmental factors like heat, light and oxidative pollutants. In addition, the analytical results clearly show that each of the two breakdown mechanisms can take place either alone or in combination, but that acid pollution suppresses oxidation. These findings were supported by the results of later studies of historical and new vegetable leathers exposed to accelerated ageing. [21-27]

Under conditions of extreme air pollution, hydrolytic breakdown will dominate. Vegetable tannins absorb sulphur dioxide in large quantities. ${ }^{[28]}$ On the other hand, experiments showed that oxidation of vegetable tannins are at minimum around $\mathrm{pH} 2.5$, increases rapidly after $\mathrm{pH} 3.5-4.6$ and is rapid under alkaline conditions. ${ }^{[29]}$ Analyses of historical leather have shown a sulphate content of more than $5 \%$ of the dry weight of the leather originating from sulphur dioxide from pollution. ${ }^{[30]}$ The acid accumulated in the leather can result in $\mathrm{pH}$ values down to around 2 , and it should be noted that the $\mathrm{pH}$ interval for maximum bonding of the vegetable tannins in the collagen is 3.5-6.0.[31]

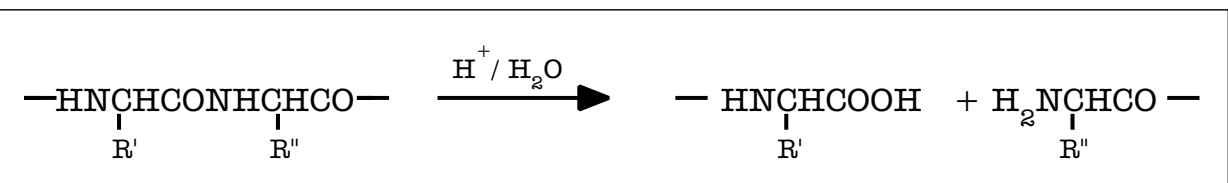

Scheme 1.

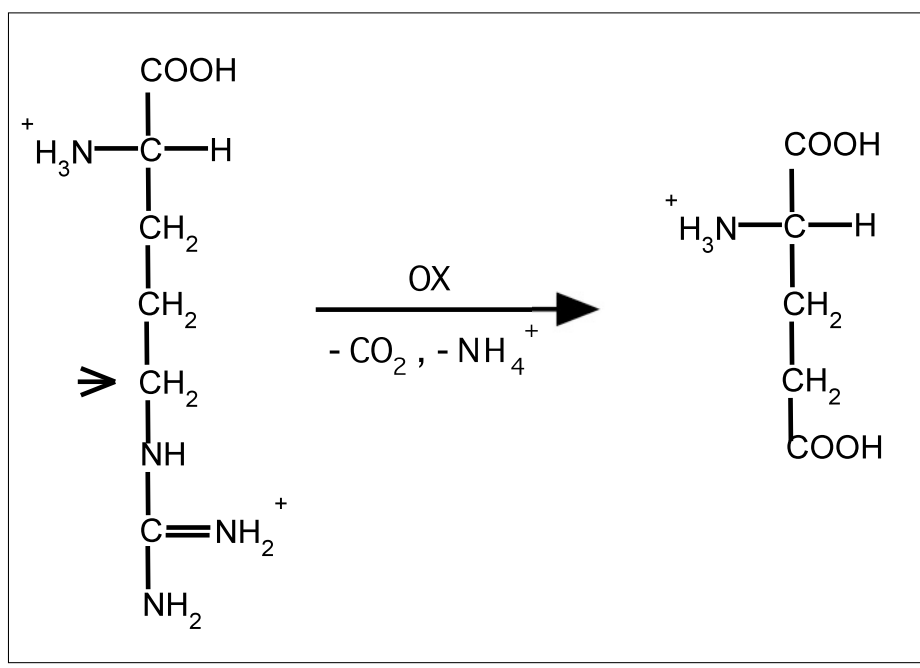

Scheme 2
As described above, oxidative breakdown involves modification of the side chains, particularly of the basic amino acids Arg, Lys and Hyl, but also Pro and Hyp. This alters the charge balance between the collagen side chains resulting in a weakening of physical stability of the leather. A low $\mathrm{pH}$ value, as caused by pollution, will contribute further to this charge-dependent destabilisation. In general, compared to new leather, deteriorated leathers are characterised by a change in the amino acid profile with lower values for Arg, Lys and Hyl and higher for Asp and Glu. It has been shown that the ratio between the sum of basic and acid amino acids (B/A) is a useful measure for the average degree of oxidation of hide collagen and leathers. ${ }^{[27,32]}$ Intact hides and leathers have a B/A value of around 0.69. The value decreases as oxidation increases, and for very strongly oxidised leather, the value is below 0.50. Moreover, both acid and oxidative sources have a deteriorative impact on the vegetable tannins and both lead to the formation of low molecular breakdown products defined as tannin monomers. ${ }^{[33,34]}$

\section{Hydrothermal Stability as a Measure of Deterioration}

Several analyses of historical and accelerated aged new vegetable tanned leathers have shown that the hydrothermal stability as determined by shrinkage temperature (Ts) is a appropriate measure of deterioration of vegetable tanned leathers. ${ }^{[35,36]}$ The shrinkage temperature, Ts, for untanned hides is around $65^{\circ} \mathrm{C}$. For vegetable tanned leather, it lies between $70{ }^{\circ} \mathrm{C}$ and $90{ }^{\circ} \mathrm{C}$. It has been demonstrated that the Ts can be predicted by multiple regression modelling based on parameters for the chemical breakdown of the collagen and tannin structures, the sulphate content and acidity of the leather as well as the interaction of these four parameters. ${ }^{[37]}$ Highly significant predictions of the observed Ts were obtained indicating the existence of several ageing profiles dependant on the type of tannins and storage conditions.

\section{Results of Recent Data Analysis}

Although it has been shown that $\mathrm{SO}_{2}$ represents the most aggressive cause of deterioration and that the degree of deterioration cannot be directly related to the age of the leather, the oxidative breakdown of the collagen seems to play a significant role over time. This can be illustrated by the data obtained by analysis of historical leathers originating from about 1660 to 1990. The leathers denoted H were sampled in Denmark, England, France and the 


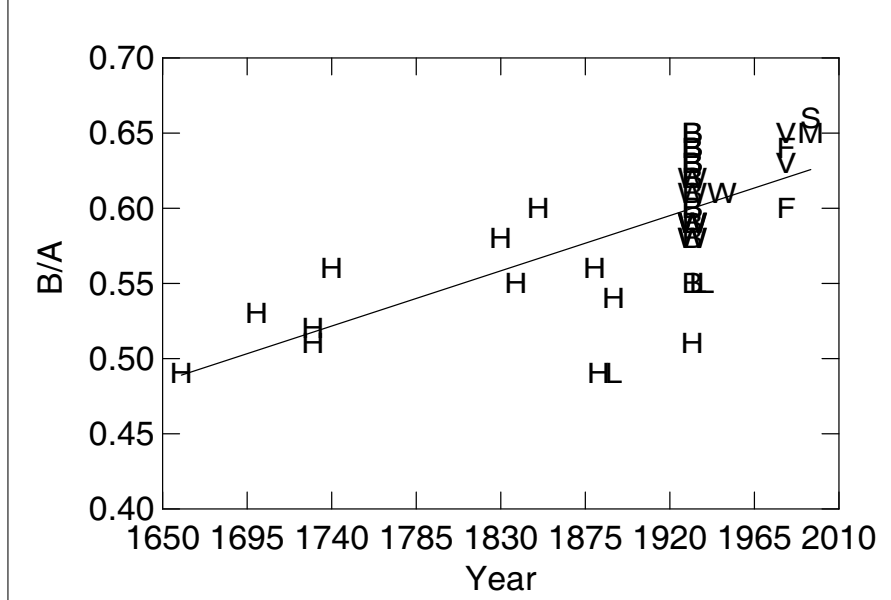

Fig. 1. Plot of $B / A$ ratios versus age of leather samples

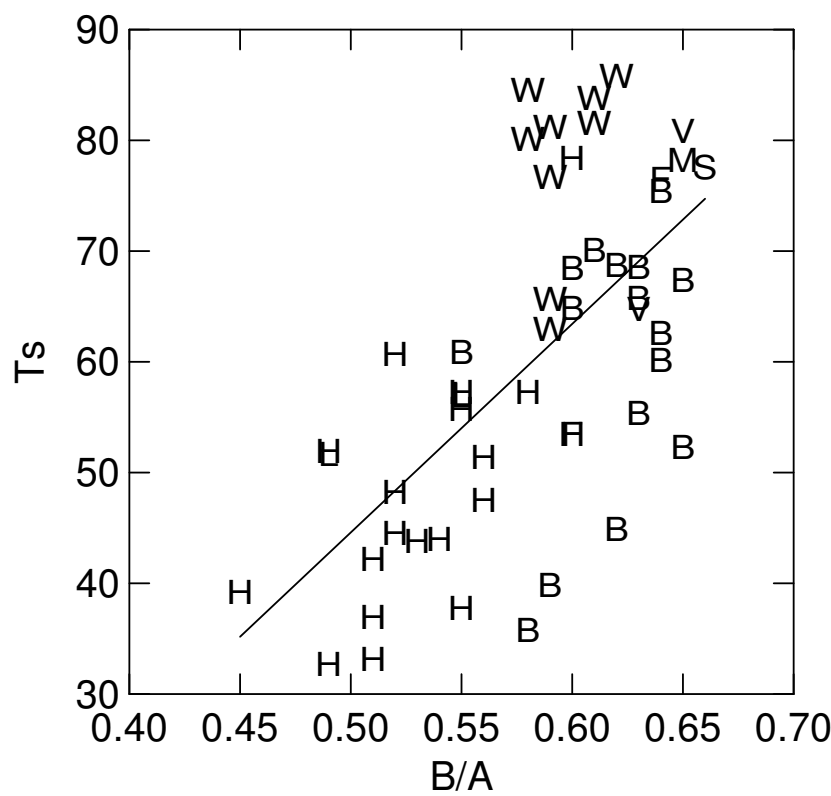

Fig. 2. Plot of shrinkage temperature $\mathrm{Ts}\left[{ }^{\circ} \mathrm{C}\right]$ versus $\mathrm{B} / \mathrm{A}$ ratios

Netherlands, ${ }^{[22]}$ leathers B and W in England and Wales, ${ }^{[22,24]}$ leathers V (after 1980) in France ${ }^{[24]}$ and leathers L, M (new) and S in Switzerland.[27]

As shown in Fig. 1, the oxidation, expressed by the B/A ratio of historical leathers, is greater in the older leathers reflected in the decrease in B/A with increasing age. It is also clear that oxidation also plays a significant role on the Ts of the leather as illustrated by the decreasing Ts with decreasing B/A as shown in Fig. 2. However, although ammonia is released by oxidation of amino acids and may influence the $\mathrm{pH}$ value in acid-damaged leathers, the impact of acid pollutants is clearly indicated in Fig. 3, show-

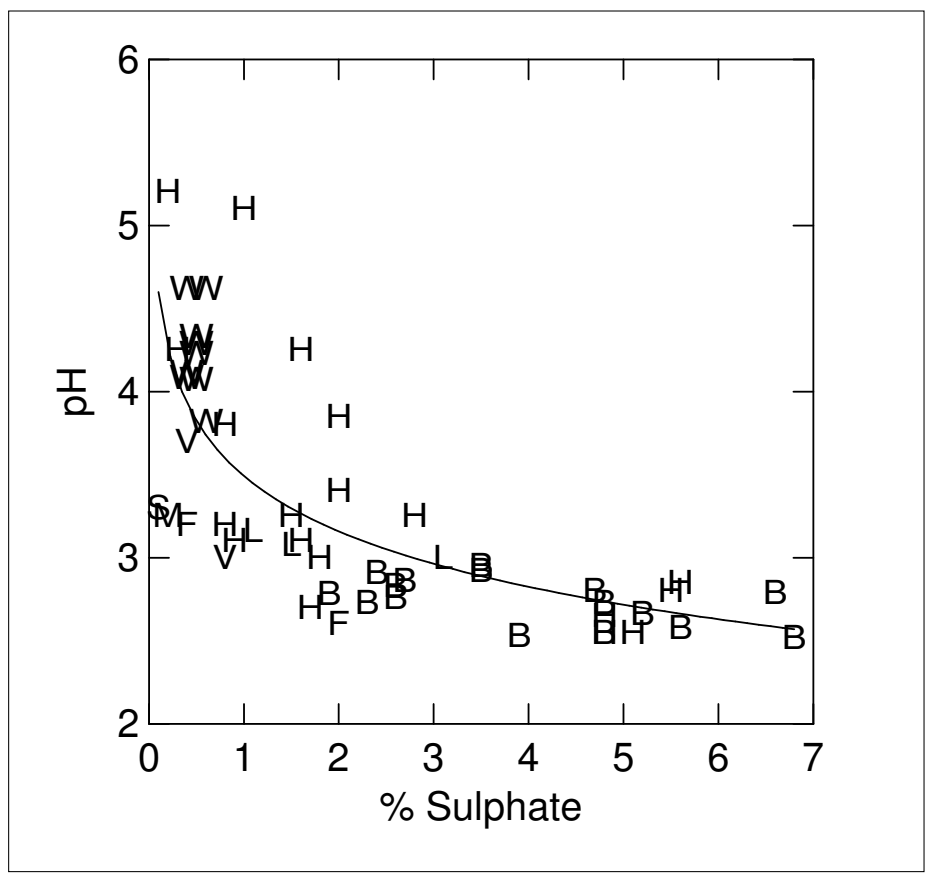

Fig. 3. Plot of measured $\mathrm{pH}$ values versus sulphate content [in $\%$ of dry weight]

ferent reaction pathways always present in natural deterioration. No matter the type of leather, this represents the big challenge for the future studies and research in the deterioration and conservation.

Received: October 10, 2008

[1] J.H. Bowes, 'Final Technical Report to United States Department of Agriculture's Agricultural Research Service', British Leather Manufacturers' Research Association, London, 1963, p. 49.

[2] R. Larsen, in 'STEP Leather Project', Ed. R. Larsen, European Commission DG XII, Research Report No. 1, Copenhagen, 1994, p. 173.

[3] R. Larsen, Beiträge zur Erhaltung von Kunst- und Kulturgut, 2004, 2, 32.

[4] M. Vest, Master Thesis (in Danish), The Royal Danish Academy of Fine Arts. School of Conservation, 1996.

[5] P. Rehak, A. Orlita, J. Thac, Das Leder 1988, 39, 107.

[6] M.V. Hannigan, J. Naghski, W. Windus, JALCA 1965, 50, 506.

[7] L. Seligsberger, C.W. Mann, in 'The Chemistry and Technology of Leather', vol. 2, Krieger Publishing Company, Huntington, 1978, p. 487.

[8] T. Klokkernes, Ph.D. Thesis, The Royal Danish Academy of Fine Arts, School of Conservation, Copenhagen, 2007.

[9] V. Barkholt, A.L. Jensen, Analytical Biochemistry 1989, 177, 318.

[10] R. Larsen, D. V. Poulsen, M. Vest, A.L. Jensen, in 'Microanalysis of Parchment', Ed. R. Larsen, Archetype Publications, London, 2002, p. 93.

[11] J. Wouters, in 'STEP Leather Project', Ed. R. Larsen, European Commission DG XII, Research Report No. 1, Copenhagen, 1994, p. 91. 
[12] J. Wouters, J. Clayes, K. Lamens, M. V. Bos, in 'Microanalysis of Parchment', Ed. R. Larsen, Archetype Publications, London, 2002, p. 13.

[13] M. Faraday, Repertory of Patent Inventions, Enlarged Series (5), vol. 2, (London), 1843, 174.

[14] D. Cockerell, J. Soc. of Arts (London) 1900, 48, 401

[15] J. G. Parker, H. C. Procter, A. SeymourJones, Appendix II in 'Report of the Committee on Leather for Bookbinding', The Society for the Encouragement of Arts, Manufactures \& Commerce, London, 1901.

[16] R. F. Innes, J. Int. Soc. of Leather Trades Chemists 1931, $X V, 480$.

[17] R. F. Innes, J. Int. Soc. of Leather Trades Chemists 1933, XVII, 725.

[18] H. Phillips, J. Soc. of Arts (London) 1954, 824.

[19] J. H. Bowes, J. E. Taylor, JALCA 1971, 96.

[20] R. Larsen, Ph.D. Thesis, University of Copenhagen, The Royal Danish Academy of Fine Arts, School of Conservation, Copenhagen, 1995.

[21] M. E. Florian, 'Protein Facts. Fibrous proteins in cultural and natural history artifacts', Archetype Publications, London, 2007.

[22] R. Larsen, in 'STEP Leather Project', Ed. R. Larsen, European Commission DG XII, Research Report No. 1, Copenhagen, 1994, p. 165.
[23] R. Larsen, C. Chahine, J. Wouters, C Calnan, in 'ICOM - CC, $11^{\text {th }}$ Triennal Meeting 1-6 September', United Kingdom, 1996, vol. II, p. 742.

[24] 'Deterioration and Conservation of Vegetable Tanned Leathers', Environment Leather Project, Ed. R. Larsen, European Commission DG XII, Research Report no. 6, Copenhagen, 1996.

[25] R. Larsen, European Cultural Heritage Newsletter on Research (special issue), 1997, 10, 54.

[26] R. Larsen, J. Wouters, F. Juchault, A. Blüher, in 'ICOM-CC, 14th Triennial meeting, 12-16 September', United Kingdom, 2005.

[27] R. Larsen, J. Wouters, F. Juchault, A. Blüher, in 'Save Paper! Mass Deacidification, Today's Experiences Tomorrow's Perspectives', Swiss National Library, 2006, p. 176.

[28] M. Santappa, V. S. S. Rao, J. Sci. And Ind. Res. 1982, 41, 705.

[29] D. G. Roux, D. Ferreira, H. K. L. Hundt, E. Malan, Applied Polymer Symposium 1982, 28, 342 .

[30] J. Wouters, in 'STEP Leather Project, Second Progress Report', Copenhagen, 1993, p. 175

[31] K. Bienkiewicz, 'Physical Chemistry of Leather Making', Krieger Publishing Company, Malabar, Florida, 1983, p. 228.

[32] R. Larsen, European Cultural Heritage Newsletter on Research 1993, 7, 1-4, 19.
[33] J. Wouters, in 'STEP Leather Project', Ed. R. Larsen, European Commission DG XII, Research Report No. 1, Copenhagen, 1994, p. 91.

[34] J. Wouters, M. Van Bos, J. Claeys, A. Oostvogels, in 'Deterioration and Conservation of Vegetable Tanned Leathers', Environment Leather Project, Ed. R. Larsen, European Commission DG XII, Research Report no. 6, Copenhagen, 1996, p. 103.

[35] R. Larsen, M. Vest, K. Nielsen in 'STEP Leather Project', Ed. R. Larsen, European Commission DG XII, Research Report No. 1, Copenhagen, 1994, p. 151.

[36] R. Larsen, M. Vest, D.V. Poulsen, U.B. Kejser, in 'Deterioration and Conservation of Vegetable Tanned Leathers', Environment Leather Project, Ed. R. Larsen, European Commission DG XII, Research Report no. 6, Copenhagen, 1996, p. 145.

[37] R. Larsen, Thermochimica Acta 2000, $365,94$.

[38] J.E. Taylor, 'Long-Period Test for Durability of Leather Book Bindings, Chemical Investigation of Used Bookbinding Leathers Removed after the Fifth (Interim) Inspection', BLMRA, L.R. 50, London, 1971. 